
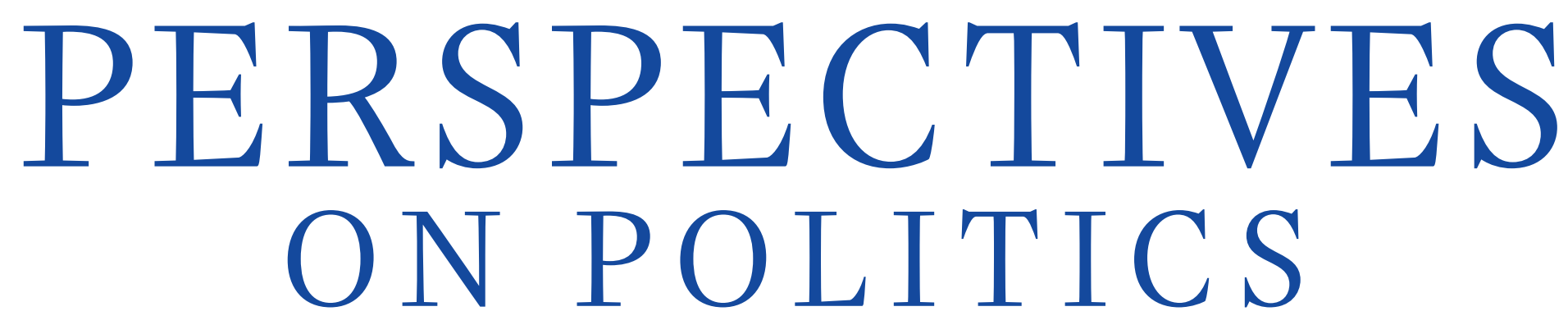

A Political Science Public Sphere | December 2019, Volume 17, Number 4

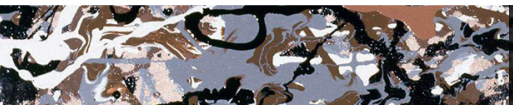

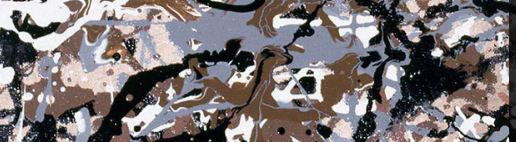 6. -16 (1) 12

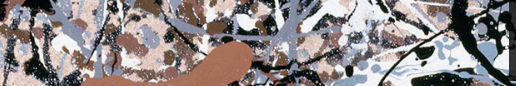 \\ Special Section: Perspectival Political Theory
}

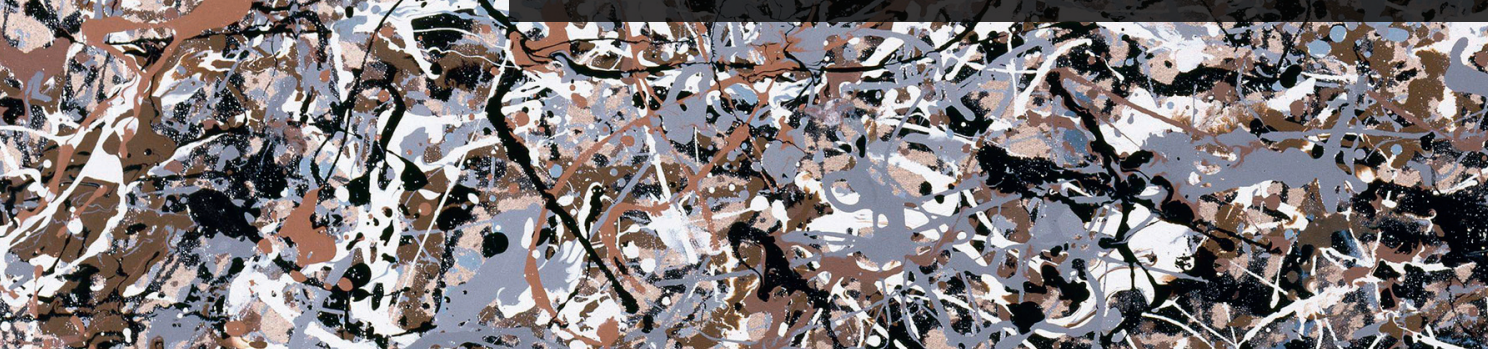
10. (x)

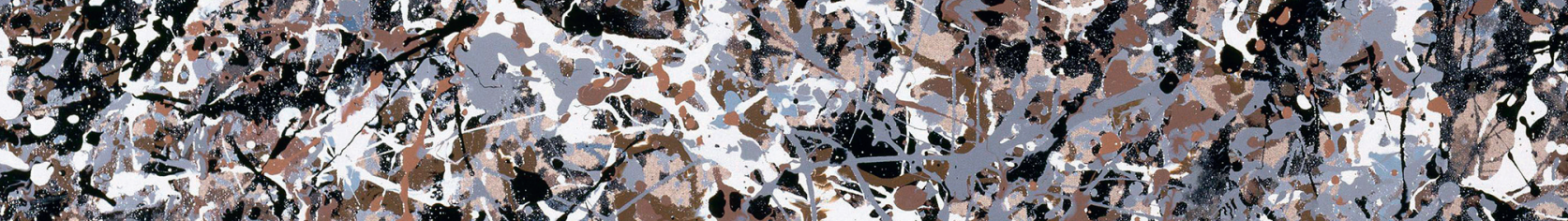

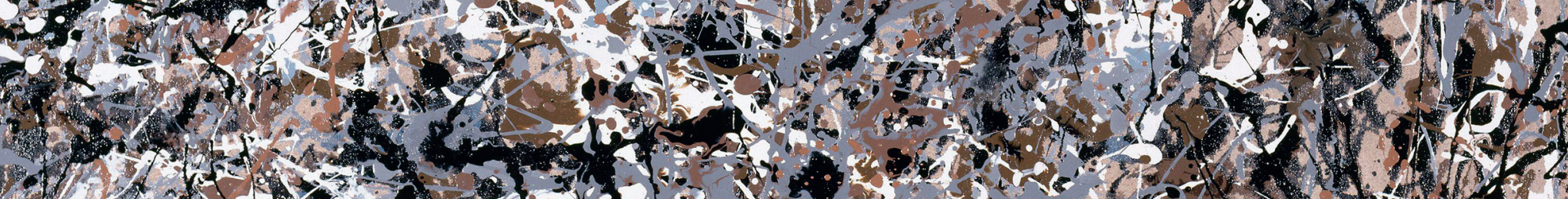

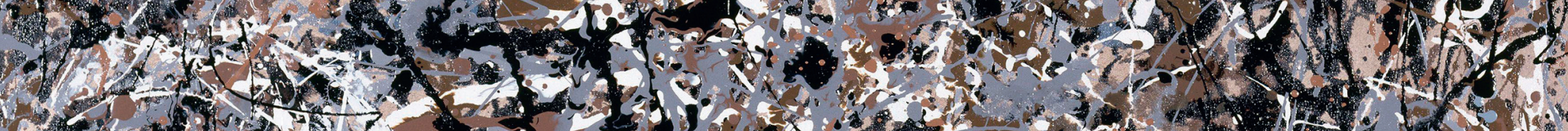

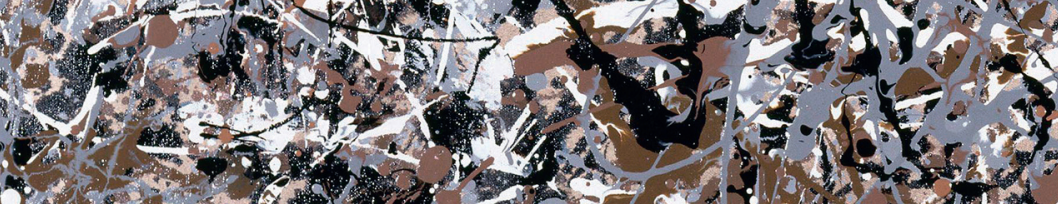

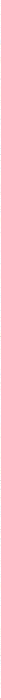




\section{Would I Do This All Over Again? Mid-Career Voices in Political Science}

\section{Read the free}

PDF online or

purchase in paperback!

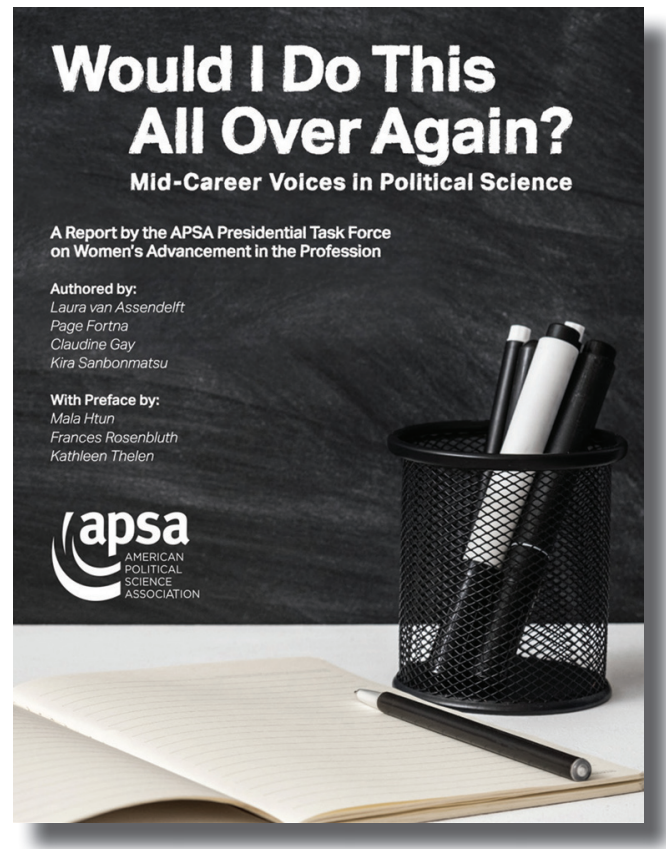

This report by the APSA Presidential Task Force on Women's Advancement in the Profession is based on personal and confidential semi-structured interviews with individuals from three graduate programs who entered graduate school around the same time (the early 1990s) about their educational and career experiences from the decision to pursue the PhD to the present-regardless of whether or not the individuals completed the degree or work in the profession today.

How do people experience the profession of political science? What explains differences in individual trajectories-both within and outside the academy? How do climate, efforts to diversify the academy, and policies such as family leave impact individual careers? What policies and practices help graduate students on the job market, and faculty on the tenure-track? What are the tradeoffs in academic and non-academic pursuits? And what is the value of the $\mathrm{PhD}$-inside and outside the academy?

\section{Scan to learn more}

\section{or visit www.apsanet.org/reports}




\section{Perspectives on Politics}

December 2019/Vol. 17, No. 4 | American Political Science Association

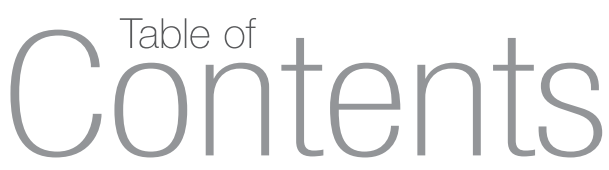

\section{From the Editors}

953 Perspectival Political Theory

Daniel O'Neill and Michael Bernhard

\section{Special Section: Perspectival Political Theory}

958 Reparations for Police Killings

Jennifer M. Page

973 An Adversarial Ethics for Campaigns and Elections Samuel Bagg and Isak Tranvik

988 Against Bot Democracy: The Dangers of Epistemic Double-Counting Ana Tanasoca

1003 Peace as a Minor, Grounded Utopia: On Prefigurative and Testimonial Pacifism Mathias Thaler

\section{Articles}

1019 The Paris Agreement on Climate Change-Made in USA? Manjana Milkoreit

1038 "I'm Not the President of Black America": Rhetorical versus Policy Representation Pavielle E. Haines, Tali Mendelberg, and Bennett Butler

1059 Interest Groups on the Inside: The Governance of Public Pension Funds Sarah F. Anzia and Terry M. Moe

1079 Who Rules the World? A Portrait of the Global Leadership Class John Gerring, Erzen Oncel, Kevin Morrison, and Daniel Pemstein

\section{Reflection}

1098 State-Making Lessons For International Relations Research Douglas Lemke

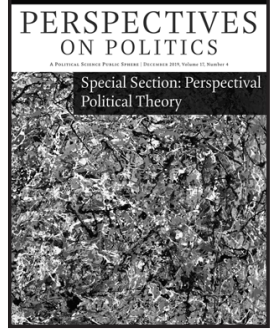

Retrato de V.I Lenin en el Estilo de Jackson Pollock VII-1980 (Portrait of V.I. Lenin in the Style of Jackson Pollock VII). Author: Art \& Language. Location: Galeria Juana de Aizpuru, Madrid, Spain. Credit: Permission granted by the gallery and the artists. 


\section{The Book Review Section}

\section{Book Review Essay}

1109 "What Are Intellectuals Good For?"

Daniel Bessner

\section{Critical Dialogues}

1115 Reviews and Responses

Adom Getachew

Worldmaking after Empire: The Rise

and Fall of Self-Determination

1121 Reviews and Responses

Begüm Adalet

Hotels and Highways: The Construction of

Modernization Theory in Cold War Turkey

1127 Reviews and Responses

Anthony Pahnke

Brazil's Long Revolution: Radical Achievements

of the Landless Workers Movement

1133 Reviews and Responses

Eva Erman and Niklas Möller

The Practical Turn in Political Theory

1139 Reviews and Responses

Christopher J. Fettweis

Psychology of a Superpower: Security

and Dominance in U.S. Foreign Policy

1144 Reviews and Responses

Nicole Bolleyer

The State and Civil Society: Regulating Interest

Groups, Parties, and Public Benefit

Organizations in Contemporary Democracies
Michael G. Hanchard

The Spectre of Race: How Discrimination

Haunts Western Democracy

Calvert W. Jones

Bedouins into Bourgeois: Remaking

Citizens for Globalization

\section{Federico M. Rossi}

The Poor's Struggle for Political Incorporation:

The Piquetero Movement in Argentina

Michael Goodhart

Injustice: Political Theory for the Real World

\section{Keren Yarhi-Milo}

Who Fights for Reputation: The Psychology of Leaders in International Conflict

\section{Stephanie L. McNulty}

Democracy from Above? The Unfulfilled

Promise of Nationally Mandated

Participatory Reforms

\section{Book Reviews}

\section{POLITICAL THEORY}

1150 Duncan Bell, ed., Empire, Race and Global Justice.

Review by Adam Dahl

1151 Shatema Threadcraft, Intimate Justice: The Black Female Body and the Body Politic.

Review by Lena Zuckerwise

1153 Sophia Rosenfeld, Democracy and Truth: A Short History.

Anna Elisabetta Galeotti, Political Self-Deception.

Review by Samuel Bagg

1154 Michael Locke McLendon, The Psychology of Inequality: Rousseau's "Amour-Propre."

Review by Joseph Reisert 
Clare Chambers, Against Marriage: An Egalitarian Defence of the Marriage-Free State.

Review by Sonu S. Bedi

1157 John S. Dryzek and Jonathan Pickering, The Politics of the Anthropocene.

Review by Peter F. Cannavò

1159 Michael J. Faber, An Anti-Federalist Constitution: The Development of Dissent in the Ratification Debates. Review by Simon Gilhooley

1160 Alexander Kaufman, Rawls's Egalitarianism.

Kasper Lippert-Rasmussen, Relational Egalitarianism: Living as Equals.

Review by Tom Parr

1162 Sina Kramer, Excluded Within: The (Un)Intelligibility of Radical Political Actors. Review by Erin R. Pineda

1164 Cécile Laborde, Liberalism's Religion. Review by Jeff Spinner-Halev

1165 Alasdair Cochrane, Sentientist Politics: A Theory of Global Inter-Species Justice. Review by Robert Garner

1166 Richard Dagger, Playing Fair: Political Obligation and the Problems of Punishment. Review by Frank Lovett

1168 Milena Tripković, Punishment and Citizenship: A Theory of Criminal Disenfranchisement. Review by Claudio López-Guerra

1169 Thomas L. Pangle, The Socratic Way of Life: Xenophon's Memorabilia. Review by Josh Vandiver

1170 André Bächtiger and John Parkinson, Mapping and Measuring Deliberation: Towards a New Deliberative Quality. Review by Edwina Barvosa

1172 Yiftah Elazar and Geneviève Rousselière, ed., Republicanism and the Future of Democracy. Review by Alan M. S. J. Coffee

1174 Arthur M. Melzer and Steven J. Kautz, ed., Are Markets Moral? Review by Emily C. Nacol

1175 Rob Reich, Just Giving: Why Philanthropy Is Failing Democracy and How It Can Do Better. Review by Ingrid Robeyns

1176 Benjamin R. Hertzberg, Chains of Persuasion: A Framework for Religion in Democracy. Review by Andrea Baumeister

\section{AMERICAN POLITICS}

1178 Todd Makse, Scott L. Minkoff, and Anand E. Sokhey, Politics on Display: Yard Signs and the Politicization of Social Spaces.

Review by Betsy Sinclair

1179 Gary C. Jacobson, Presidents and Parties in the Public Mind. Review by Sidney Milkis

1181 Bernard L. Fraga, The Turnout Gap: Race, Ethnicity, and Political Inequality in a Diversifying America. Review by Ricardo Ramirez

1183 Joshua J. Dyck and Edward L. Lascher, Jr., Initiatives without Engagement: A Realistic Appraisal of Direct Democracy's Secondary Effects. Review by Daniel R. Biggers

Jay K. Dow, Electing the House: The Adoption and Performance of the U.S. Single-Member District Electoral System. Review by James D. King

1185 Lynda G. Dodd, ed., The Rights Revolution Revisited: Institutional Perspectives on the Private Enforcement of Civil Rights in the US. Review by Jeffrey Abramson

1187 Sidney M. Milkis and Daniel J. Tichenor, Rivalry and Reform: Presidents, Social Movements, and the Transformation of American Politics. Review by David S. Meyer

1188 Ben Merriman, Conservative Innovators: How States Are Challenging Federal Power. Review by Shanna Rose

1189 Jeffrey R. Henig, Rebecca Jacobsen, and Sarah Reckhow, Outside Money in School Board Elections: The Nationalization of Education Politics. Review by Domingo Morel

1191 Doris Marie Provine, Monica W. Varsanyi, Paul G. Lewis, and Scott H. Decker, Policing Immigrants: Local Law Enforcement on the Front Lines. Review by Abigail Fisher Williamson

1192 Robert M. Alexander, Representation and the Electoral College. Review by Burdett A. Loomis

1194 Matthew Dean Hindman, Political Advocacy and Its Interested Citizens: Neoliberalism, Postpluralism, and LGBT Organizations.

Review by Susan Burgess 
1195 Kristina C. Miler, Poor Representation: Congress and the Politics of Poverty in the United States. Review by Christopher Faricy

1197 Terry M. Moe, The Politics of Institutional Reform: Katrina, Education, and the Second Face of Power. Review by Clarence N. Stone

1198 Aaron S. King, Unfolding Ambition in Senate Primary Elections: Strategic Politicians and the Dynamics of Candidacy Decisions.

Review by Robert G. Boatright

1199 Kim L. Fridkin and Patrick J. Kenney, Taking Aim at Attack Advertising: Understanding the Impact of Negative Campaigning in U.S. Senate Races.

Review by Amber Wichowsky

1201 Josh M. Ryan, The Congressional Endgame: Interchamber Bargaining and Compromise. Review by Laine P. Shay

\section{COMPARATIVE POLITICS}

1202 Ethan J. Hollander, Hegemony and the Holocaust: State Power and Jewish Survival in Occupied Europe.

Robert Braun, Protectors of Pluralism: Religious Minorities and the Rescue of Jews in the Low Countries During the Holocaust.

Review by Volha Charnysh

1204 Salwa Ismail, The Rule of Violence: Subjectivity, Memory and Government in Syria. Review by Wendy Pearlman

Dennis C. Grube, Megaphone Bureaucracy: Speaking Truth to Power in the Age of the New Normal. Review by Jonathan Moss

1207 Yonatan L. Morse, How Autocrats Compete: Parties, Patrons, and Unfair Elections in Africa. Review by Natalie Wenzell Letsa

Thomas Hegghammer, ed., Jihadi Culture: The Art and Social Practices of Militant Islamists. Review by Gilbert Ramsay

1211 Valeria Palanza, Checking Presidential Power: Executive Decrees and the Legislative Process in New Democracies.

Review by Juan Pablo Micozzi

Iza R. Hussin, The Politics of Islamic Law: Local Elites, Colonial Authority, and the Making of the Muslim State. Review by Dörthe Engelcke

David J. Samuels and Cesar Zucco, Partisans, Antipartisans, and Nonpartisans: Voting Behavior in Brazil. Review by Frederico Batista Pereira

1215 Jack Corbett and Wouter Veenendaal, Democracy in Small States: Persisting Against All Odds. Review by Dag Anckar

Selina Ho, Thirsty Cities: Social Contracts and Public Goods Provision in China and India. Review by Mark W. Frazier

Jennie L. Schulze, Strategic Frames: Europe, Russia, and Minority Inclusion in Estonia and Latvia. Review by Erin Jenne

As'ad Ghanem and Mohanad Mustafa, Palestinians in Israel: The Politics of Faith after Oslo. Review by Ilan Peleg

Michaël Aklin, Patrick Bayer, S. P. Harish, and Johannes Urpelainen, Escaping the Energy Poverty Trap: When and How Governments Power the Lives of the Poor. Review by Elizabeth Chatterjee

Sara Niedzwiecki, Uneven Social Policies: The Politics of Subnational Variation in Latin America. Review by Natasha Borges Sugiyama

A. Kadir Yildirim, Muslim Democratic Parties in the Middle East: Economy and Politics of Islamist Moderation. Review by Tarek Masoud

1226 James Loxton and Scott Mainwaring, eds., Life after Dictatorship: Authoritarian Successor Parties Worldwide. Review by John T. Ishiyama

John James Kennedy and Yaojiang Shi, Lost and Found: The “Missing Girls" in Rural China. Review by Christina Maags

Curtis R. Ryan, Jordan and the Arab Uprisings: Regime Survival and Politics Beyond the State. Review by Jason Brownlee

1230 Michael S. Danielson, Emigrants Get Political: Mexican Migrants Engage Their Home Towns.

Adrián Félix, Specters of Belonging: The Political Life Cycle of Mexican Migrants. Review by Alexandra Délano Alonso

Matthew Rhodes-Purdy, Regime Support Beyond the Balance Sheet: Participation and Policy Performance in Latin America.

Review by Kirk A. Hawkins

Matt Buehler, Why Alliances Fail: Islamist and Leftist Coalitions in North Africa. Review by Jean Lachapelle 
J. Christopher Soper and Joel S. Fetzer, Religion and Nationalism in Global Perspective. Review by Paul A. Djupe

1237 Annette Idler, Borderland Battles: Violence, Crime, and Governance at the Edges of Colombia's War. Review by Abbey Steele

1238 Oren Barak, State Expansion and Conflict: In and Between Israel/Palestine and Lebanon. Review by James Worrall

1240 Michael Koß, Parliaments in Time: The Evolution of Legislative Democracy in Western Europe, $1866-2015$. Review by Amie Kreppel

1241 Dina Bishara, Contesting Authoritarianism: Labor Challenges to the State in Egypt. Review by Lisa Blaydes

1242 Gwyneth H. McClendon, Envy in Politics. Review by George E. Marcus

1244 Mohammad Ayatollahi Tabaar, Religious Statecraft: The Politics of Islam in Iran. Review by Shabnam Holliday

1245 Fanie du Toit, When Political Transitions Work: Reconciliation as Interdependence.

Gabrielle Lynch, Performances of Injustice: The Politics of Truth, Justice and Reconciliation in Kenya.

Abena Ampofoa Asare, Truth Without Reconciliation: A Human Rights History of Ghana. Review by Sebastian Elischer

\section{INTERNATIONAL RELATIONS}

1247 Sarah Blodgett Bermeo, Targeted Development: Industrialized Country Strategy in a Globalizing World.

Dan Honig, Navigation by Judgment: Why and When Top-Down Management of Foreign Aid Doesn't Work. Review by Matthew S. Winters

1249 Lilach Gilady, The Price of Prestige: Conspicuous Consumption in International Relations. Review by Gwyneth H. McClendon

1251 Ariel I. Ahram, Break All the Borders: Separatism and the Reshaping of the Middle East. Review by Ryan D. Griffiths

1252 Piki Ish-Shalom, Beyond the Veil of Knowledge: Triangulating Security, Democracy, and Academic Scholarship. Review by Daniel J. Levine

1254 Erik Gartzke and Jon R. Lindsay, eds., Cross-Domain Deterrence: Strategy in an Era of Complexity. Review by Chris C. Demchak

Sylvia Bashevkin, Women as Foreign Policy Leaders: National Security and Gender Politics in Superpower America. Review by Kristen P. Williams

1256 Adam Hanieh, Money, Markets, and Monarchies: The Gulf Cooperation Council and the Political Economy of the Contemporary Middle East. Review by Gerd Nonneman

1258 James H. Lebovic, Planning to Fail: The US Wars in Vietnam, Iraq, and Afghanistan. Review by Dominic Tierney

1259 James David Meernik and Kimi Lynn King, Judging Justice: How Victim Witnesses Evaluate International Courts. Review by David Mendeloff

1261 Marcus Schulzke, Pursuing Moral Warfare: Ethics in American, British, and Israeli Counterinsurgency. Review by Valerie Morkevičius

1262 Van Jackson, On the Brink: Trump, Kim, and the Threat of Nuclear War. Review by Jongseok Woo

1263 Mark Raymond, Social Practices of Rule-Making in World Politics. Review by Stephen Pampinella

1265 Christine Sylvester, Curating and Re-Curating the American Wars in Vietnam and Iraq. Review by Jessica Auchter

1266 Matthew Kroenig, The Logic of American Nuclear Strategy: Why Strategic Superiority Matters. Review by Todd S. Sechser

1267 Rachel M. Stein, Vengeful Citizens, Violent States: A Theory of War and Revenge. Review by Terrence L. Chapman

1269 Clifford Bob, Rights as Weapons: Instruments of Conflict, Tools of Power. Review by Joel R. Pruce 


\section{Philosophy of Perspectives on Politics}

Perspectives seeks to nurture a political science public sphere, publicizing important scholarly topics, ideas, and innovations, linking scholarly authors and readers, and promoting broad reflexive discussion among political scientists about the work that we do and why this work matters.

A full-length copy of the journal's editorial philosophy appears in Perspectives on Politics 8(1): 7-10 and also on the web at https://www.apsanet.org/perspectivessubmissions.

\section{Submission and Review}

For submission guidelines, please see https://www.apsanet.org/perspectivessubmissions.

Our editorial team discusses all submissions. Those that seem promising are eval-

uated by several external reviewers - with full confidentiality on both sides - and then accepted, returned for further revisions, or declined with suggestions of more appropriate venues for publication.

\section{CONTACT INFO}

Perspectives on Politics

Department of Political Science

1507 W. University Avenue

PO Box 117325 Anderson Hall

University of Florida

Gainesville, FL 32611

Perspectives: perspectives@apsanet.org

Book Reviews: perspectives-reviews@polisci.ufl.edu

\section{Perspectives on Politics}

Editor

Michael Bernhard, University of Florida, 2017

Associate Editor and Book Review Editor

Daniel I. O'Neill, University of Florida, 2017-

Managing Editor

Jennifer C. Boylan, University of Florida, 2017 -

Assistants to the Editor

Stephanie Denardo Marah Schlingensiepen

Alec Dinnin

Dragana Svraka

Peter R. Licari

Editors Emeritus

Jeffrey C. Isaac, Indiana University, 2009-2017

James Johnson, University of Rochester, 2005-2008

Jennifer Hochschild, Harvard University, 2002-2005

Editorial Board

Resat Bayer, Koç University

Cristina Beltran, New York University

Richard Bensel, Cornell University

Ruth Berins Collier, University of California at Berkeley

Nancy Bermeo, Oxford University

Charli Carpenter, University of Massachusetts, Amherst

Simone Chambers, University of California, Irvine

Katherine Cramer, University of Wisconsin-Madison

Zsolt Enyedi, Central European University

Michael Goodhart, University of Pittsburgh

Anna Grzymala-Busse, Stanford University

Michael Hanchard, University of Pennsylvania

Juliet Hooker, Brown University

Jane Junn, University of Southern California

Daniel Kapust, University of Wisconsin-Madison

Douglas Lemke, Penn State University

Julia Lynch, University of Pennsylvania

Marc Lynch, George Washington University

Samantha Majic, John Jay College, CUNY

Kathleen McNamara, Georgetown University

Suzanne Mettler, Cornell University

Jørgen Møller, Aarhus University

Cas Mudde, University of Georgia

Anja Neundorf, University of Glasgow

Daniel Nexon, Georgetown University

Erin O'Brien, University of Massachusetts, Boston

Michael Leo Owens, Emory University

Christopher Parker, University of Washington

Andrew Sabl, University of Toronto

Ed Schatz, University of Toronto

Dan Slater, University of Michigan

Joe Soss, University of Minnesota

Paul Staniland, University of Chicago

Joan C. Tronto, University of Minnesota

Ashutosh Varshney, Brown University

Vesla Weaver, Johns Hopkins University

Deborah J. Yashar, Princeton University
Association Office Address and Membership Information: American Political Science Association individual membership dues are as follow: Regular members with income $\$ 200,000+$ $\$ 325 ; \$ 135,000-\$ 199,999, \$ 276 ;$ \$100,000 - \$134,000, \$246; $\$ 80,000-\$ 99,999, \$ 212 ; \$ 60,000-\$ 79,999, \$ 191 ; \$ 50,000$ $-\$ 59,999, \$ 175 ; \$ 40,000-\$ 49,999, \$ 145$; less than $\$ 40,000$, $\$ 98$; Retired members with income $\$ 25,000+, \$ 66$; Retired members with income less than \$25,000, \$40; Targeted international member (TIM), \$45; Life member, \$4,000; K -12 (PS only), \$50; Unemployed members, \$45; Student members, \$52; Associate member with one journal selection, \$75. Changes of address for members should be completed online or mailed to the APSA membership office at: APSA, 1527 New Hampshire Avenue, N.W., Washington, DC 20036

Subscription, Publishing, and Advertising Office Address: Cambridge University Press, One Liberty Plaza, Floor 20, New York, NY 10006; and (for correspondents outside the United States, Canada, and Mexico) Cambridge University Press, Journals Fulfillment Department, UPH, Shaftesbury Road, Cambridge CB2 8BS, England.

Subscription Information: Perspectives on Politics (ISSN 1537 5927) is published quarterly, in March, June, September, and December, by Cambridge University Press (One Liberty Plaza, 20th floor, New York, NY 10006) for the American Political Science Association. Annual institutional electronic-only subscription rate (2019) is US\$1642 in the United States, Canada, and Mexico; $£ 943$ elsewhere. Annual institutional print and electronic subscription rate (2019) is US\$1903 in the United States, Canada and Mexico; £1080 elsewhere. Perspectives on Politics is sold only as part of a joint subscription with the American Political Science Review and PS: Political Science \& Politics. Single part rate (2019) is US\$191 in the United States, Canada and Mexico; £109 elsewhere. Periodicals postage rate paid at New York, NY, and additional mailing offices

Postmaster: Send address changes to Perspectives on Politics, Cambridge University Press, Journals Fulfillment Department One Liberty Plaza, Floor 20, New York, NY 10006, U.S.A Send address changes elsewhere to Perspectives on Politics, Cambridge University Press, Journals Fulfillment Department, UPH, Shaftesbury Road, Cambridge CB2 8BS, England.

(c) American Political Science Association 2019

All rights resenved. No part of this publication may be reproduced, in any form or by any means, electronic, photocopying, or otherwise, without permission in writing from Cambridge University Press. Policies, request forms, and contacts are available from: http://www.cambridge.org/rights/permissions/ permission.htm

Permission to copy (for users in the U S.A.) is available from the Copyright Clearance Center, http://www.copyright.com email: info@copyright.com.

Advertising: Perspectives on Politics has a circulation of 16,000. For information on advertising rates and mechanical requirements, contact Advertising Coordinator, Cambridge University Press, One Liberty Plaza, Floor 20, New York, NY 10006. (212) 337-5000.

Composition: TNQ Books and Journals Pvt. Ltd., Chennai, India. Printing and Distribution: The Sheridan Press, Hanover, PA. 


\section{About APSA}

Founded in 1903, the American Political Science Association is the leading professional organization for the study of political science and serves more than 12,000 members in over 80 countries. With a range of programs and services for individuals, departments, and institutions, APSA brings together political scientists from all fields of inquiry, regions, and occupational endeavors within and outside academe in order to deepen our understanding of politics, democracy, and citizenship throughout the world.

The direct advancement of knowledge is at the core of APSA activities. We promote scholarly communication in political science through a variety of initiatives including publishing four distinguished journals: American Political Science Review, Perspectives on Politics, PS: Political Science \& Politics, and the Journal of Political Science Education.

\section{Officers}

\section{PRESIDENT}

Paula D. McClain

Duke University

VICE-PRESIDENTS

Kerstin Hamann

University of Central Florida

Leonard Wantchekon

Princeton University

Melissa Williams

University of Toronto

\section{Council}

2017-2020

Joseph Carens

University of Toronto

Lisa Garcia-Bedolla

University of

California, Berkeley

Lilly J. Goren

Carroll University

Simon Jackman

University of Sydney

Matthew Kocher

Johns Hopkins

University

Erin Richards

Cascadia College

University of

Valeria Sinclair-Chapman California, Irvine

Purdue University

Laura Sjoberg

University of Florida

of Technology

Charlotte

Lori J. Marso

Union College

Alberto Simpser

Rocío Titiunik

\section{PRESIDENT-ELECT \\ Janet Box-Steffensmeier \\ Ohio State University}

PAST PRESIDENT

Rogers Smith

University of Pennsylvania

TREASURER

Thomas Pepinsky

Cornell University

EXECUTIVE DIRECTOR

Steven Rathgeb Smith

$\begin{array}{ll}\mathbf{2 0 1 8 - 2 0 2 1} & \mathbf{2 0 1 9 - 2 0 2 2} \\ \text { Adam J. Berinsky } & \text { Ben Ansell } \\ \text { Massachusetts Institute } & \text { University of Oxford }\end{array}$

Ann O'M. Bowman

Texas A\&M University

Julia S. Jordan-Zachery University of Illinois at

University of North Carolina, Chicago

Instituto Tecnológico

Autónomo de México

Erik Bleich

Middlebury College

Alexandra Filindra

Rebecca Gill

University of Nevada, Las

Vegas

Soo Yeon Kim

National University of

Singapore

David Leal

University of Texas, Austin

Suzanna Linn

Penn State University

Princeton University

Lisa Wedeen

University of Chicago
Melanye Price

Prairie View A\&M

University

Former APSA Presidents

Frank J. Goodnow

Albert Shaw

Frederick N. Judson

James Bryce

A. Lawrence Lowell

Woodrow Wilson

Simeon E. Baldwin

Albert Bushnell Hart

W. W. Willoughby

John Bassett Moore

Ernst Freund

Jesse Macy

Munroe Smith

Henry Jones Ford

Paul S. Reinsch

Leo S. Rowe

William A. Dunning

Harry A. Garfield

James W. Garner

Charles E. Merriam

Charles A. Beard

William Bennett Munro

Jesse S. Reeves

John A. Fairlie

Benjamin F. Shambaugh

Edward S. Corwin

William F. Willoughby

Isidor Loeb

Walter Shepard

Francis W. Coker

Arthur N. Holcombe

Thomas Reed Powell

Clarence A. Dykstra

Charles Grove Haines

Robert C. Brooks

Frederic A. Ogg

William Anderson

Robert E. Cushman

Leonard D. White

John Gaus

Walter F. Dodd

Arthur W. MacMahon

Henry R. Spencer

Quincy Wright

James K. Pollock

Peter H. Odegard

Luther Gulick

Pendleton Herring

Ralph J. Bunche

Charles McKinley

Harold D. Lasswell

E. E. Schattschneider

V. O. Key, Jr.

R. Taylor Cole

Carl B. Swisher

Emmette S. Redford

Charles S. Hyneman
Carl J. Friedrich

C. Herman Pritchett

David B. Truman

Gabriel A. Almond

Robert A. Dahl

Merle Fainsod

David Easton

Karl W. Deutsch

Robert E. Lane

Heinz Eulau

Robert E. Ward

Avery Leiserson

Austin Ranney

James MacGregor Burns

Samuel H. Beer

John C. Wahlke

Leon D. Epstein

Warren E. Miller

Charles E. Lindblom

Seymour Martin Lipset

William H. Riker

Philip E. Converse

Richard F. Fenno

Aaron B. Wildavsky

Samuel P. Huntington

Kenneth N. Waltz

Lucian W. Pye

Judith N. Shklar

Theodore J. Lowi

James Q. Wilson

Lucius J. Barker

Charles O.Jones

Sidney Verba

Arend Lijphart

Elinor Ostrom

M. Kent Jennings

Matthew Holden, Jr.

Robert O. Keohane

Robert Jervis

Robert D. Putnam

Theda Skocpol

Susanne Hoeber Rudolph

Margaret Levi

Ira Katznelson

Robert Axelrod

Dianne M. Pinderhughes

Peter Katzenstein

Henry E. Brady

Carole Pateman

G. Bingham Powell, Jr.

Jane Mansbridge

John H. Aldrich

Rodney E. Hero

Jennifer Hochschild

David Lake

Kathleen Thelen

Rogers Smith

APSA | 1527 New Hampshire Avenue, NW | Washington, DC 20036 | 202-483-2512 | www.apsanet.org 


\section{Access Your Journals through the APSA Website}

Go to apsanet.org and click "Login" in the upper right corner
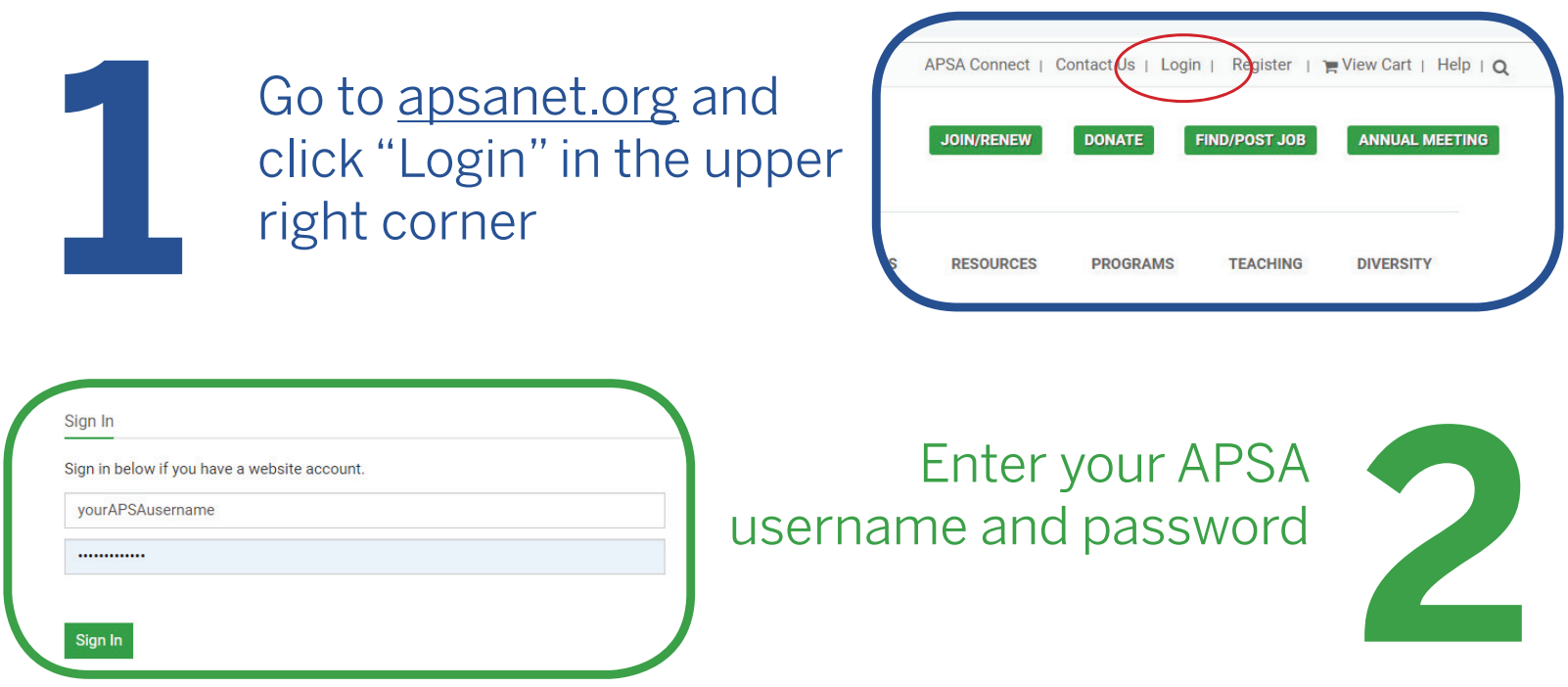

Enter your APSA username and password
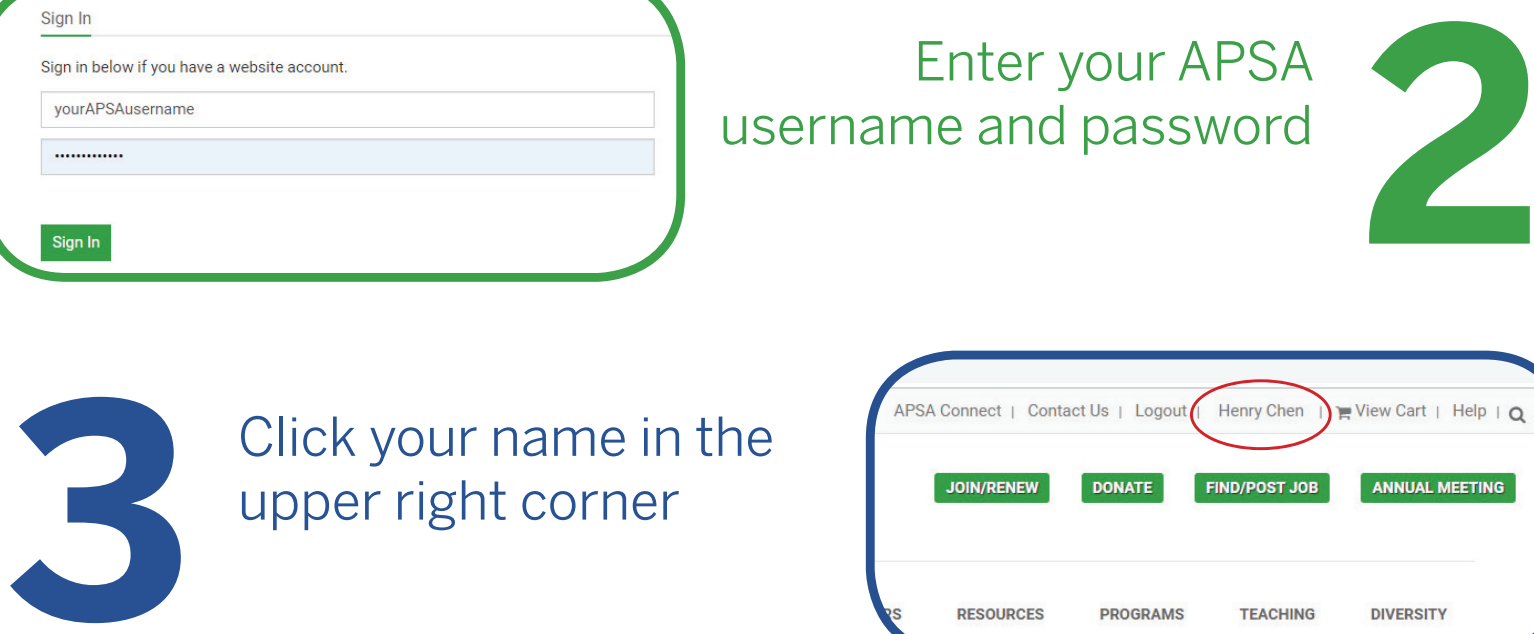

Click your name in the upper right corner
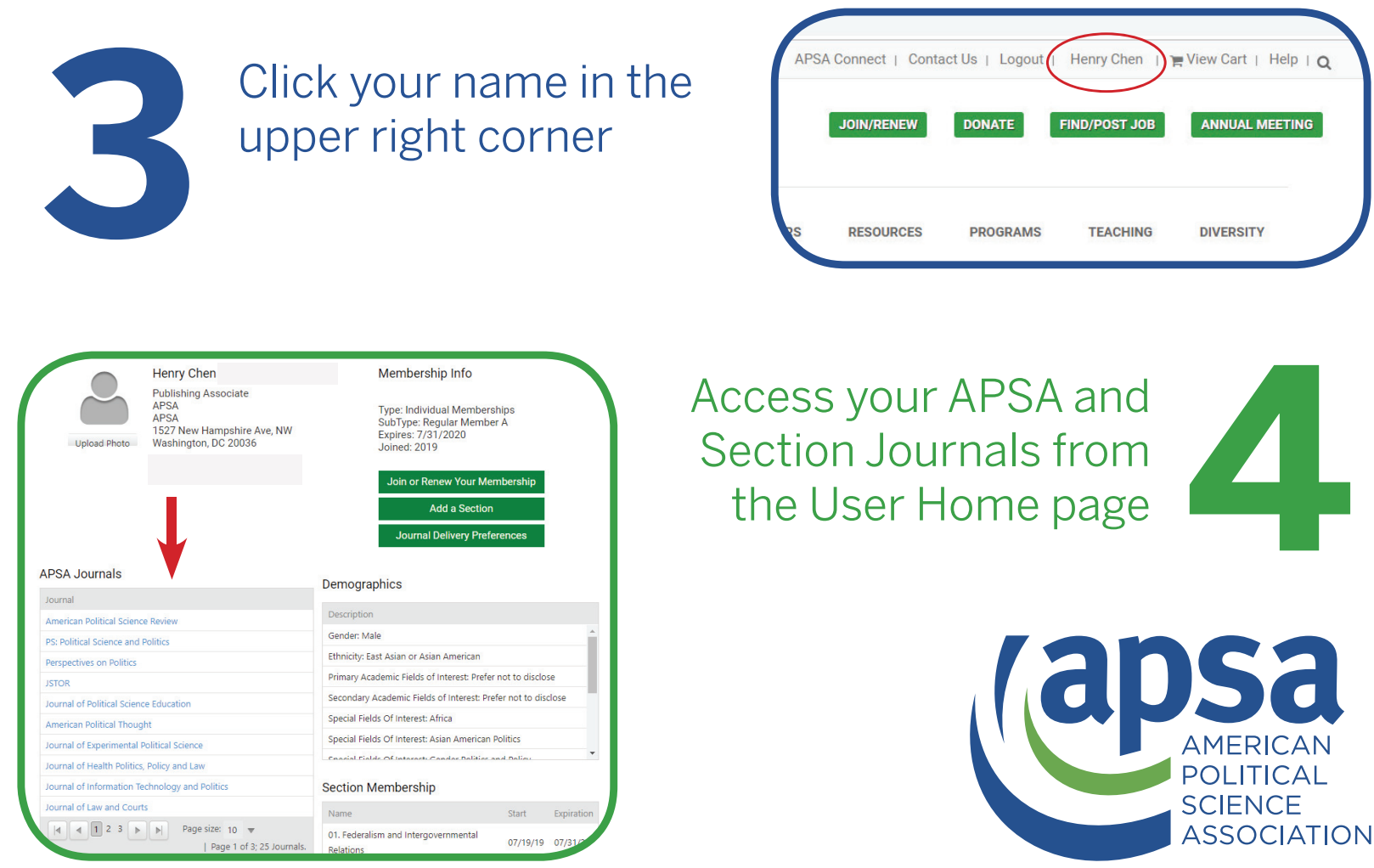

Access your APSA and Section Journals from the User Home page

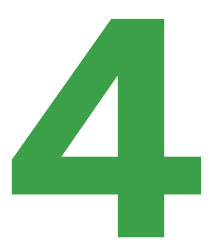

